Correction: MUC1-C integrates activation of the IFN- $\gamma$

pathway with suppression of the tumor immune

\title{
microenvironment in triple-negative breast cancer
}

Yamashita N, Long M, Fushimi A, et al. MUC1-C integrates activation of the IFN- $\gamma$ pathway with suppression of the tumor immune microenvironment in triple-negative breast cancer. J Immunother Cancer. 2021;9:e002115. doi: 10.1136/jitc-2020-002115.

This article has been corrected since it first published. The provenance and peer review statement has been added.

Open access This is an open access article distributed in accordance with the Creative Commons Attribution 4.0 Unported (CC BY 4.0) license, which permits others to copy, redistribute, remix, transform and build upon this work for any purpose, provided the original work is properly cited, a link to the licence is given, and indication of whether changes were made. See https://creativecommons.org/licenses/by/4.0/.

(c) Author(s) (or their employer(s)) 2021. Re-use permitted under CC BY. Published by BMJ.

J Immunother Cancer 2021;9:e002115corr1. doi:10.1136/jitc-2020-002115corr1

A) Check for updates 